\title{
EFFECT OF NITROGEN AND BIO-FERTILIZATION WITH DIFFERENT PLANTING DISTANCES ON IMPROVING THE GROWTH AND QUALITY OF BEET YIELD AND ITS EFFECT ON DIGESTION BY IN-VITRO GAS PRODUCTION TECHNIQUE.
}

\author{
Fatma SH. Ismail ${ }^{1}$ and Azza M. M. Badr ${ }^{2}$ \\ ${ }^{1}$ Forage Crop, Res. Sec., Field crop, Res., Inst., Agric. Res. Center, Giza, Egypt. \\ ${ }^{2}$ Regional Center for food and feed, Agric. Res. Cent. Giza, Egypt. Email: azzabadr805@yahoo.com
}

(Received 10/10/2019, accepted 28/11/2019)

\section{SUMMARY}

$\mathrm{T}$ his study was contacted to investigate the effects of row spacing and different rate of mineral nitrogen fertilization with / or without Bio-fertilizer on fodder beet productivity, quality and soil properties. We evaluated the effects of $\mathrm{N}$ level placement at rate of $60,90,120 \mathrm{~kg} / \mathrm{fed}$ with and without bio-fertilizer and row spacing. The treatments content : A1: $58 \mathrm{~cm}, \mathrm{~A} 2: 76 \mathrm{~cm}, \mathrm{~T} 1: 60 \mathrm{~kg} / \mathrm{fed} \mathrm{N}$. without bio- fertilizer, T2: 60kg/ fed $\mathrm{N}$ with bio- fertilizer, T3: $90 \mathrm{~kg} /$ fed N. without bio- fertilizer, T4: $90 \mathrm{~kg} /$ fed $\mathrm{N}$ with bio- fertilizer, T5: $120 \mathrm{~kg} /$ fed $\mathrm{N}$ without bio- fertilizer and T6: $120 \mathrm{~kg} / \mathrm{fed} \mathrm{N}$ with bio- fertilizer. The results showed that the nitrogen application on number of leaves and root diameter value were nonsignificantly increased 47.38 and $14.43 \mathrm{~cm}$ for T6, while the root length value $53.25 \mathrm{~cm}$ for T4 was significantly increased. The highest values of fresh and dry leaves in T4 were 6.90 and 0.90 ton/fed as effected by applying nitrogen fertilizer at rate of $90 \mathrm{~kg} \mathrm{~N} / \mathrm{fed}$ with bio-fertilizer under $76 \mathrm{~cm}$ row spacing, while the highest values of fresh and dry root yield in T1 were 71.93 and 10.51 ton/fed, respectively. We may conclude that using as soil application $90 \mathrm{~kg} \mathrm{~N}^{-1} \mathrm{fe}^{-1}$ inter row spacing $58 \mathrm{~cm}$ could led to improving soil chemical properties, which in turn led to producing the highest root and leaves of fodder beet yield/ fed. The highest crude protein and fiber observed with leaves and roots under density row in (A2) $76 \mathrm{~cm}$ spaces compared with spacing raw $58 \mathrm{~cm}(\mathrm{~A} 1)$, while NFE\% content had a significant decrease with applying nitrogen fertilizer alone or combined with bio fertilizer with leaves and roots under (A2) the values were 49.57, 68.21 compared with (A1). The T6 (120 $\mathrm{kg} / \mathrm{fed} \mathrm{N}+$ bio-fertilizer) recorded the highest values in crude protein while were 14.99 and 12.91 in laves and roots, respectively, while the highest value in crude fiber was obtained from $60 \mathrm{~kg}^{\text {fed }}{ }^{-1}$ nitrogen treatment without bio-fertilizer (T1), where values were 25.23 and $8.01 \%$, respectively. In addition, the values of NFE\% decrease significantly in T6. The values were increased significantly for IV-DMD\%, GP (ml/200mgDM), IVDOM\% and ME (MJ/kg DM) under (A2) $76 \mathrm{~cm}$ spaces between rows compared with spacing raw $58 \mathrm{~cm}$ (A1) in leaves. While the roots were increased in GP, IV-DOM\% and ME (MJ / kg DM) from 29.04 (ml/200mgDM), $77.33 \%$ and10.20(MJ/kg DM) spacing raw $58 \mathrm{~cm}$ (A1) to $31.95(\mathrm{ml} / 200 \mathrm{mgDM}), 81.79 \%$ and $11.02(\mathrm{MJ} / \mathrm{kg}$ DM) density of row in (A2) $76 \mathrm{~cm}$ spaces, respectively. The treatment T6 recorded the highest value in leaves. while in the root the highest value recorded on treatment T5 in GP, IV-DOM\% and ME (MJ/kg DM) analysis, where the values are $42.12(\mathrm{ml} / 200 \mathrm{mg} \mathrm{DM}), 86.92 \%$ and $11.95(\mathrm{MJ} / \mathrm{kg} \mathrm{DM})$, respectively except IV-DMD\% were recorded high value $63.37 \%$ were recorded with T1. and GPSF with T2. These significantly increase may be due to short chain fatty acid (SCFA mmol/ml gas), Gas production structure fractions (GPSF ml/g DM), Gas production non structure fractions (GPNSF ml/g DM) and Microbial protein (MP g/kg DOM) in (A2) $76 \mathrm{~cm}$ spaces between row compared with spacing raw $58 \mathrm{~cm}$ (A1) in beet roots. The values are 1.10, 5.14, 48.18 and 79.54, respectively. In the other hand, the beet leaves are insignificant due to short chain fatty acids (SCFA $\mathrm{mmol} / \mathrm{ml}$ gas), Gas production structure fractions (GPSF ml/g DM), Gas production non structure fractions (GPNSF $\mathrm{ml} / \mathrm{g} \mathrm{DM}$ ) and Microbial mas production (MP $\mathrm{g} / \mathrm{kg}$ DOM) the mineral nitrogen fertilizer alone and spacing row in (A1) $58 \mathrm{~cm}$ compared with spacing row in (A2) $76 \mathrm{~cm}$. The treatment T6 $(120 \mathrm{~kg} / \mathrm{fed} \mathrm{N}+\mathrm{bio}-$ fertilizer) recorded highest value SCFA mmol/ml gas, Gas production nonstructural fractions GPNSF (ml/g $\mathrm{DM}$ ) and Microbial protein (MP g/kg DOM) in leaves, where the values are 1.18, 51.61 and 82.30. while for the root where highest value recorded for treatment T5 $(120 \mathrm{~kg} \mathrm{~N} /$ fed without bio- fertilizer) in short chain fatty acids (SCFA mmol/ml gas). Gas production nonstructural fractions (GPNSF ml/g DM) and Microbial protein (MP g/kg DOM), where the values are 1.76, 70.70 and 104.30, respectively. The roots have an excellent feed quality and they are very palatable to ruminant stock. This increase was attributed to the positive effect of fertilizers on the root growth, which consequently led to increasing the absorption of different nutrients. Fodder beet has extremely high yield potential when grown on high fertile soils. Fodder beet requires large amounts of nitrogen. In conclusion nitrogen fertilization has a positive effect on diameter and length of roots. The highest growth with nitrogen fertilization was associated with bio-fertilization. The quality and production of tubers were increased by increasing the distance between rows by increasing the nitrogen rates and giving the highest 


\section{Ismail and Badr}

percentage of raw protein in roots with the nitrogen rate of $120 \mathrm{~kg}$ of T6 highest amount of leaves with high digestive value, while recorded the highest digestive value of roots recorded with the T5.

Keywords: nitrogen levels, Bio-fertilizer, Row spacing, Growth, Yield, Chemical composition, Digestible gas test, soil properties and Fodder beet.

\section{INTODUCTION}

Fodder beet has extremely high yield potential when grown on high fertile soils. Fodder beet requires large amounts of nitrogen. Nitrogen fertilizers are one of the major costs for production of these crops (Abdel-Gwad et al. 2008, Sarhan and Ismail 2003). Zamfir et al. (2001) and Zaki (1999) reported those increasing nitrogen fertilizations led to increasing dry matter yield and crude protein content of fodder beet. Previous studies with fodder beet indicated that the nitrogen rates influenced root yield and yield components (Yüksel et al. 2009, Prokopenko et al. 1997, Geweifel and Aly 1996 and Karczmarczyk et al. 1995). However, field experiments on the effects of nitrogen rates and harvest time on the root yield and quality components are very limited in fodder beet.

Bio-fertilizers application can lead to increasing the availability of nutrients by their biological activity and help to improve the soil health. Microbes involved in the formulation of bio-fertilizers not only mobilize $\mathrm{N}$ and $\mathrm{P}$ but increase the process of producing crops and foods naturally. This method avoids the use of synthetic chemical fertilizers and genetically modified organisms to influence the growth of crops (Ramdan et al. 2013). Plant growth promotes rhizobacteria through the cycling and availability of nutrients where led to increasing the health of the roots during the growth stage by increasing the absorption of nutrients (Vessey, 2003). Feeding of green forage to livestock is essential for the maintenance of normal health and reproduction (Roy and Khandaker, 2010). Beet is an excellent high energy source and economic milking and fattening feed for both dairy and beef cattle, especially when fed in combination with high quality silage. These crops are used because they are high yielding and typically have high metabolizable energy (ME) content of over $12 \mathrm{MJ} / \mathrm{kg}$ dry matter (DM), even at advanced stages of maturity Judson and Edwards (2008).

Recently in vitro gas production technique with chemical composition have been widely used to evaluate the potential nutritive value of previously uninvestigated forages since in vitro gas production technique is quick, cheap and less time consuming (Maheri - Sis et al. 2008 \& 2007, Chumpawadee et al. 2005 and Getachew et al. 2004). In vitro rumen degradability and gas production (GP) techniques have been used for estimating quality of feed fodder beet for ruminants. The gas production of different classes of feed incubated in vitro in buffered rumen fluid was closely related to the production of SCFA, $\mathrm{s}$ which was based on carbohydrates fermentation (Kanak et al. 2012, Sallam et al. 2007 and Blummel \& Oraskov 1993).

Fodder beet has a dietary effect, being easily digestible. Fodder beet is an excellent feed for dairy cows, increasing milk production and it makes possible the decreasing of concentrates quantity. It can be chopped and mixed with grounded concentrate fodders. Fodder beet can be fed until late autumn and winter, after feeding with green forage (Halga P. and col., 2000). The diet is not balanced and does not correspond to dairy cows' nutrient needs. This is what makes fodder beet excellent forage in this type of farms. Recently in vitro gas production technique with chemical composition have been widely used to evaluate the potential nutritive value of previously uninvestigated forages since in vitro gas production technique is quick, cheap and less time consuming (Kamalak and Canbolat 2010, Maheri-Sis et al. 2008 and 2007, Chumpawadee et al. 2005 and Getachew et al. 2004).

The objective of this study was to investigation the mineral nitrogen fertilizer with different rates alone or combined with bio-fertilizer and row spacing on availability of roots and leaves of fodder beet productivity, growth, mineral elements and Quality. The final product in the recent paper was determining on digestibility artificial rumen by gas test production.

\section{MATERIALS AND METHODS}

Site and sample collection: Two field experiments were carried out at Sides Agricultural Research Station, Bani Seweif Governorate (Middle Egypt), Agricultural Research Center, Ministry of Agriculture, Egypt, during two successive seasons of winter 2015/2016 and 2016/2017. Some soil physical and chemical 
properties were determined before sowing according to the methods described by Cottenie et al. (1982) and Page et al. (1982). Bio-fertilizer Rhizobium radiobacter sp. strain (salt tolerant PGPR) Production Unit, Department of Microbiology, Soils, Water and Environment Research Institute, Agric. Res. Cent., Giza, Egypt.

Experimental design: In both seasons each experiment was carried out in a split-split plot design with six treatments and three replicates: A1: $58 \mathrm{~cm}, \mathrm{~A} 2: 76 \mathrm{~cm}, \mathrm{~T} 1: 60 \mathrm{~kg} / \mathrm{fed}$ N. without bio- fertilizer, T2: 60kg/ fed $\mathrm{N}$ with bio- fertilizer, T3: $90 \mathrm{~kg} /$ fed $\mathrm{N}$. without bio- fertilizer, T4: $90 \mathrm{~kg} /$ fed N with bio- fertilizer, T5: $120 \mathrm{~kg} /$ fed $\mathrm{N}$ without bio- fertilizer and T6: $120 \mathrm{~kg} /$ fed $\mathrm{N}$ with bio- fertilizer. The used bio-fertilizer Rhizobium radiobacter sp. strain was arranged randomly as main plot, the $\mathrm{N}$ level was allowed at sub -sub Plot and the spaces between raw were distributed randomly as Sub - sub blot. The experimental plot size was $(2 \mathrm{~m} \times 3 \mathrm{~m})=6 \mathrm{~m}^{2}$. The soil was disc-ploughed, harrowed twice, leveled and ridged 65 and $76 \mathrm{~cm}$ apart. The experimental area was divided two divisions for first division without bio-fertilizer and second division with bio-fertilizer. Harvesting is usually carried out from April through last September. The biofertilizer was adhesive liquid (Arabic gum). Seeds were thoroughly mixed with the inoculation in the shade, then sown immediately and covered with soil in order to minimize Rhizobium radiobacter sp. exposure to the sun. Two of coated seeds were sown in hole with $5 \mathrm{~cm}$ depth. The distance between each two holes was $25 \mathrm{~cm}$. After 30 days from planting was manual thinned to one plant. The same time freshly collected leaves samples from each plot were cut into small pieces and dried for determining chemical analysis.

Table (1): Physical and chemical properties in soil under study.

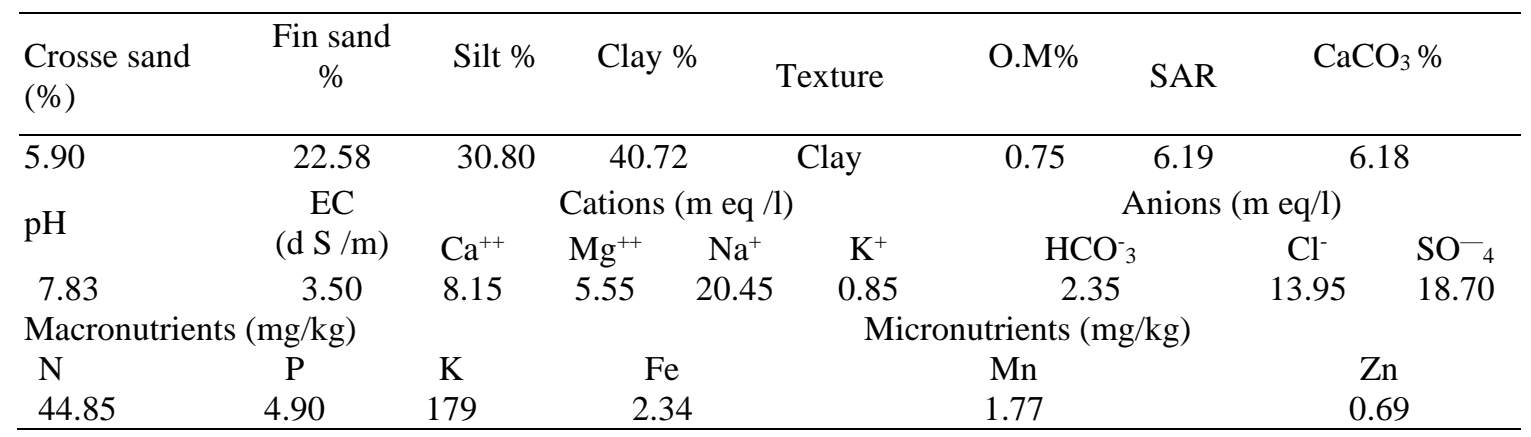

Urea $(46 \% \mathrm{~N})$ was applied as $\mathrm{N}$ fertilizer at rate of 60,90 and120 $\mathrm{kg} / \mathrm{fed}$ on three equal doses after 30 , 55 and 85 days after sowing. Potassium sulphate $\left(48 \mathrm{~K}_{2} \mathrm{O}\right)$ was applied at a rate $100 \mathrm{~kg} / \mathrm{fed}$ on three doses after 30, 45 and 60 days after sowing. Super phosphate $\left(15.5 \% \mathrm{P}_{2} \mathrm{O}_{5}\right)$ was applied at rate $200 \mathrm{~kg} /$ fed during tillage soil. Seeds of fodder beet were Monoverse cultivar. At harvest after five months from sowing, when plants showed signs of maturity which is indicated by leaf yellowing and partial drying of the lower leaves, six plants per plot from the inner two ridges were randomly hand-pulled to determine root length $(\mathrm{cm})$, roots diameter $(\mathrm{cm})$, fresh and dry weights (ton/fed) of leaves and root.

Chemical composition: Samples were sieved after dried and milled through a $1 \mathrm{~mm}$ sieve for chemical composition of crude protein, crude fiber and ether extract and ash were determined according to AOAC (2000). The contents of macro-micronutrients in leaves and root were determined in plant digestion using the methods described by Cottenie et al. (1982) and Page et al. (1982).

In- vitro gas production techniques: Gas production test was carried out in the laboratory of Total Nutrient Digestibility, Regional center for food and feed, Giza. Egypt. The samples were incubated in vitro with rumen fluid in calibrated glass syringes following the procedures of Menke et al. (1979). Two hundred milligram dried samples were weighed in triplicate into calibrated glass syringes of $100 \mathrm{ml}$. The syringes were prewar med at $39^{\circ} \mathrm{C}$ before the injection of $30 \mathrm{ml}$ rumen fluid- buffer mixture into each syringe followed by incubation in a water bath at $39^{\circ} \mathrm{C}$. Reading of gas production was recorded before incubation 0 and 2, 4, 6, 8, 24, $48 \mathrm{~h}$ after incubation. Total gas values were corrected, digestible dry matter (IV-DDM), digestible organic matter (IV-DOM), short chain fatty acids (SCFA), metabolizable energy (ME) and net energy lactation (NEL) values in experimental by- products were calculated using equations as below according to Menke et al. (1979). Gas production soluble fraction (GPSF) and gas production non- soluble fraction (GPNSF) were calculated according to van Gelder et al. (2005), metabolizable energy (ME), net 


\section{Ismail and Badr}

energy lactation (NEL), organic matter digestibility (IV-OMD) and dry matter digestibility (IV-DMD) values were calculated using equations below according to Menke and Steingass (1988).

In vitro digestibility crude protein intake (IV-DCPI) $(\mathrm{G} /$ day $)=(-203.242 * 14.797)+\mathrm{GP} 24+6.249 * \mathrm{GP} 48)$. In vitro digestibility organic matter intake (IV-DOMI) $(\mathrm{g} /$ day $)=(-1763.07+42.5 * \mathrm{PG} 24)+13.52 * \mathrm{GP} 48)$. Short chain fatty acid $(\mathrm{SCFA})(\mathrm{mmol} / \mathrm{ml}$ gas $)=(0.0239 * \mathrm{GP}+0.0601) . \quad$ (van Gelder et al., 2005)

Gas production structure fraction $(\mathrm{GPSF})(\mathrm{ml} / \mathrm{g} \mathrm{DM})=(\mathrm{GP} 3 \mathrm{~h}-5.5) * 0.99-3$.

Gas production non- structure fraction GPNSF $(\mathrm{ml} / \mathrm{g} \mathrm{DM})=(1.02 *(\mathrm{GP} 24 \mathrm{~h}-5.5)-(\mathrm{GP} 3 \mathrm{~h}-5.5)+2)$.

Net energy $(\mathrm{NE})(\mathrm{M}$ cal./Lb. $)=(2.2+(0.0272 *$ gas $)+(0.057 * \mathrm{cp})+(0.149 * \mathrm{EE}) / 14.64$. (Manke and steingass, 1988)

Metabolic energy $(\mathrm{ME})(\mathrm{MJ} / \mathrm{kg} \mathrm{DM})=2.04+0.1448 * \mathrm{GP}+0.0036 \mathrm{CP}+0.0243 \mathrm{EE}$.

Net energy lactation $(\mathrm{NEL})(\mathrm{MJ} / \mathrm{Kg} \mathrm{DM})=0.08+0.1101 \mathrm{GP}+0.0022 \mathrm{CP}+0.0161$.

$\mathrm{MP}=$ Microbial protein $\mathrm{g} / \mathrm{kg}(\mathrm{DOM})=120 * \mathrm{DOM} / 100$. (Czerkawski, 1986)

Statistical analysis: The statistical analysis was done using MSTAT- C program in a completely Randomized Design (CRD), and differences among the treatment means were determined by the least Significant Difference (LSD) for comparing means at 5\% level was calculated according to Gomez and Gomez (1984).

\section{RESULTS AND DISCUSSION}

\section{Fodder beet yield and growth:}

Data presented in Table (2) showed that the effect of mineral nitrogen fertilizer alone and spacing row in (A1) $58 \mathrm{~cm}$ lad to increasing in fresh and dry leaves and roots, number of leaf's compared with spacing row in (A2) $76 \mathrm{~cm}$. The utilization of bio-fertilizer caused non-significantly increase in weight of fresh and dry leaves yield (ton/fed) for fodder beet in T4 compared with other treatment but mineral nitrogen fertilizer alone recorded highly significant increase of fresh and dry root yield (ton /fed) with T1. This result agrees with Khogali et al. (2011) who found that the effected of nitrogen high rate (120 kg /ha) and wider spacing had significant increase of shoot fresh weight. In additional Kandil et al. (2004) suggested that the effect of bio-fertilizer had effect on the growth of plant, which reflected to yield increase. This increase may be due to of $\mathrm{N}$ was produced by bacteria species, in addition of some growth regulators like IAA and $\mathrm{GA}_{3}$ which stimulated growth. Fodder beet is particularly productive and is the highest yielding crop grown under temperate climates. Abo-El-Goud (2000) found that using bio-fertilizer had a positive effect on the weight of the fresh and dry root. The spacing levels effects between rows were not significant for fresh leaves yield, while was significant for dry leaves yield. Interaction effects between nitrogen different rate alone or combined with bio - fertilizer and spacing rows for fresh weight yield were not significant. The increase in root yield and leaves yield /fed with the increasing in nitrogen levels alone or combined with bio-fertilizer may be attributed to the role of nitrogenous in enhancing growth, chlorophyll formation and photosynthesis process.

The highest values of root length $53.25 \mathrm{~cm}$ with $\mathrm{T} 4$, root diameter $14.23 \mathrm{~cm}$ with $\mathrm{T} 6$ and number of leaves $47.38 \mathrm{~cm}$ with T3 for fodder beet treated with nitrogen different rate and spacing $76 \mathrm{~cm}$ between rows. Mustafa (2007) working on sugar beet in the Sudan suggested that the nitrogen element may be play an important role in increasing cell elongation and cell division. As well as the increase of root length and root diameter as affected by bio fertilizer reflect to some growth regulators like IAA and GA3 which stimulated growth produced These results disagree with the obtained by Khogali et al. (2012) who indicated that the increasing mineral nitrogen fertilizer rate and wider spacing led to increase of root diameter. Also, Amin et al. (2013) found that application of nitrogen fertilizer at the rate of $100 \mathrm{~kg} / \mathrm{fed}$ recorded the highest values in root length and root diameter for sugar beet. This increasing in root length and root diameter may be reflecting using of nitrogen with respect of row spacing and high nitrogen rate.

The highest number of leaves is significantly increased $47.38 \mathrm{~cm}$ in T3. The leaves and roots growth parts are used to feed animals but, the main fodder is tuberous roots (Ibrahim, 2005). Therefore, the optimum population which produces maximum leaves and roots growth and hence productivity must be carefully determined. 
Table (2): Effect of different mineral nitrogen fertilizer rate alone or combined with bio-fertilizer and density row on growth and weight yield of fodder beet.

\begin{tabular}{|c|c|c|c|c|c|c|c|}
\hline $\begin{array}{l}\text { Rate of } N \\
(\mathrm{~kg} / \mathrm{fed}) \mathrm{B}\end{array}$ & $\begin{array}{c}\text { Fresh } \\
\text { weight 0f } \\
\text { leaves } \\
\text { (ton/fed) }\end{array}$ & $\begin{array}{c}\text { Dry } \\
\text { weight of } \\
\text { leaves } \\
\text { (ton/fed) }\end{array}$ & $\begin{array}{c}\text { Fresh weight } \\
\text { Of root } \\
\text { (ton/fed) }\end{array}$ & $\begin{array}{c}\text { Dry } \\
\text { weight of } \\
\text { root } \\
\text { (ton/fed) }\end{array}$ & $\begin{array}{c}\text { Number } \\
\text { of leaf }\end{array}$ & $\begin{array}{c}\text { Root } \\
\text { diameter } \\
(\mathrm{cm})\end{array}$ & $\begin{array}{l}\text { Root } \\
\text { length } \\
(\mathrm{cm})\end{array}$ \\
\hline A1 & 6.65 & 0.86 & 78.28 & 11.69 & 47.25 & 13.81 & 51.04 \\
\hline $\mathrm{A} 2$ & 5.91 & 0.73 & 53.90 & 7.70 & 45.54 & 13.50 & 51.46 \\
\hline LSD $0.05 \mathrm{~A}$ & 0.65 & 0.08 & 2.80 & 0.75 & 1.23 & Ns & Ns \\
\hline $\mathrm{T} 1$ & 5.66 & 0.73 & 71.93 & 10.51 & 45.88 & 13.65 & 49.63 \\
\hline $\mathrm{T} 2$ & 6.00 & 0.75 & 67.58 & 9.88 & 46.75 & 13.51 & 52.38 \\
\hline $\mathrm{T} 3$ & 6.41 & 0.84 & 68.85 & 10.37 & 47.38 & 13.65 & 49.88 \\
\hline $\mathrm{T} 4$ & 6.90 & 0.90 & 65.78 & 9.93 & 45.63 & 13.01 & 53.25 \\
\hline T5 & 5.81 & 0.73 & 61.43 & 9.03 & 45.50 & 13.68 & 49.88 \\
\hline T6 & 6.90 & 0.83 & 60.98 & 8.44 & 47.25 & 14.43 & 52.50 \\
\hline LSD $0.05 \mathrm{~B}$ & n.s. & n.s. & 3.53 & 0.64 & n.s. & n.s. & 2.69 \\
\hline $\mathrm{A} 1 \times \mathrm{T} 1$ & 5.70 & 0.74 & 85.65 & 12.42 & 46.25 & 14.05 & 49.50 \\
\hline $\mathrm{A} 1 \times \mathrm{T} 2$ & 6.08 & 0.78 & 78.45 & 12.26 & 46.50 & 14.50 & 52.50 \\
\hline A 1 x T3 & 6.45 & 0.86 & 75.00 & 11.81 & 48.00 & 13.53 & 51.50 \\
\hline A 1 x T4 & 7.80 & 1.02 & 85.80 & 12.61 & 45.75 & 13.10 & 51.25 \\
\hline A1 x T5 & 6.53 & 0.88 & 76.20 & 11.07 & 44.75 & 13.80 & 50.25 \\
\hline A 1 x T6 & 7.35 & 0.89 & 68.55 & 9.95 & 52.25 & 13.90 & 51.25 \\
\hline A 2 xT1 & 5.63 & 0.72 & 58.20 & 8.59 & 45.50 & 13.25 & 49.75 \\
\hline $\mathrm{A} 2 \times \mathrm{T} 2$ & 5.93 & 0.73 & 56.70 & 7.50 & 47.00 & 12.52 & 52.25 \\
\hline A $2 \times \mathrm{T} 3$ & 6.38 & 0.81 & 56.55 & 8.93 & 46.75 & 13.78 & 48.25 \\
\hline $\mathrm{A} 2 \times \mathrm{T} 4$ & 6.00 & 0.77 & 51.90 & 7.24 & 45.50 & 12.93 & 55.25 \\
\hline A $2 \times \mathrm{T} 5$ & 5.10 & 0.57 & 46.65 & 6.94 & 46.25 & 13.55 & 49.50 \\
\hline A $2 \times \mathrm{T} 6$ & 6.45 & 0.78 & 53.40 & 7.00 & 42.25 & 14.95 & 53.75 \\
\hline $\begin{array}{l}\text { LSD } 0.05 \text { A } \\
\text { X B }\end{array}$ & Ns & Ns & 4.99 & 0.91 & 4.77 & Ns & 3.80 \\
\hline
\end{tabular}

A1: $58 \mathrm{~cm}, A 2: 76 \mathrm{~cm}, T 1: 60 \mathrm{~kg} / \mathrm{fed} \mathrm{N}$. without bio-fertilizer, T2: 60kg/fed N with bio-fertilizer, T3: $90 \mathrm{~kg} / \mathrm{fed} \mathrm{N}$. without bio-fertilizer, T4: $90 \mathrm{~kg} / \mathrm{fed} \mathrm{N}$ with bio-fertilizer, T5: $120 \mathrm{~kg} / \mathrm{fed} N$ without bio-fertilizer and T6: $120 \mathrm{~kg} / \mathrm{fed} \mathrm{N}$ with bio-fertilizer.

\section{Effect of different mineral $N$ fertilizer rate and spacing of row on some soil properties}

\section{Soil clay lemon $\left(\mathrm{EC} \mathrm{dSm}^{-1}\right)$.}

Data presented in Table (3) showed significant effect of row spacing between rows on soil clay lemon. Increasing the row spacing led to increasing of soil clay. The increase in row spacing led to accumulation of salt on surface layer because of increasing the evaporation. The effect of bio-fertilizer combined with mineral nitrogen led to decreasing of soil clay lemon may be to the microorganism's product of organic matter led to improving soil aggregation, water movement and leaching the excessive soluble salts. On the other hand, the increase of mineral nitrogen rate led to decreasing of soil clay lemon. These results are in agree that with those obtained by Siam et al. (2013) who found that the effect of $\mathrm{N}$ rates application was reducing the soil clay lemon. Tarek et al. (2008) reported that the soil clay lemon was significantly reduced from $60 \mathrm{dSm}^{-1}$ to about $17 \mathrm{dSm}^{-1}$, for the leached fodder beet.

\section{Soil pH:}

Data presented in Table (3) demonstrated that the effect of mineral $\mathrm{N}$ - fertilizer different rates alone or combined with bio-fertilizer and spacing rows on soil $\mathrm{pH}$ had positive effect specially soil treated with high mineral nitrogen combined with bio-fertilizer and low spacing rows.

These results are in agreement with those obtained by Shaban and Omar (2006) who suggested that the increasing mineral nitrogen levels of combined with bio-fertilizer led to decreasing soil $\mathrm{pH}$. Abd El-Ghany et al. (2010) indicated that inoculation of seeds by Rhizobiummay be led to increasing the uptake of N, P and $\mathrm{K}$. Wu et al. (2006) found that, the activity of bacteria Bacillus mucilaginous, led to an increase of water 
dissolved organic carbon concentration and a decreased $\mathrm{pH}$ value, which enhanced macronutrients mobility and bio-availability in soil. Seeds of fodder beet inoculation may be attributed to $\mathrm{N}_{2}$-fixation which reduced to the soil $\mathrm{pH}$ especially in the rhizosphere, thereby increase the availability of most essential macro- and micro-nutrients (Kandil et al., 2004). Root yield was influenced by $\mathrm{N}$ fertilizer and may be increased by increasing rate of $\mathrm{N}$ supplying (Bahman et al., 2013).

\section{Macronutrient N, P and $K$ availability in studied soil:}

Data in Table (3) showed that the macronutrients N, P and $\mathrm{K}$ available in soil may be increased with increasing mineral nitrogen fertilizer rate alone or combined with bio-fertilizer. In addition, the effect of space (A2) $76 \mathrm{~cm}$ between rows on $\mathrm{N}$ and $\mathrm{K}$ available in soil are decreased significantly, while the $\mathrm{P}$ available in soil was non-significantly decrease, values are 50.03,190 and 5.40, respectively. The values of macronutrients $\mathrm{N}$ and $\mathrm{K}$ in soil are increased significantly 58.10 and $200 \%$ in T6 but the $\mathrm{P}$ value is nonsignificant increased $6.22 \%$. These results showed that the increase was attributed to the positive effect of

Table (3): Effect of different mineral nitrogen fertilizer rate alone or combined with bio-fertilizer and density row on some chemical properties of soil.

\begin{tabular}{|c|c|c|c|c|c|}
\hline \multirow{2}{*}{$\begin{array}{l}\text { Rate of } \mathrm{N} \\
(\mathrm{kg} / \mathrm{fed}) \mathrm{B} \\
\text { Density of row }(\mathrm{cm}) \mathrm{A}\end{array}$} & \multirow{2}{*}{$\begin{array}{c}\mathrm{pH} \\
(1: 2.5)\end{array}$} & \multirow{2}{*}{$\mathrm{EC}\left(\mathrm{dsm}^{-1}\right)$} & \multicolumn{3}{|c|}{ Concentration of Macronutrients (\%) for soil } \\
\hline & & & $\mathrm{N}$ & $\mathrm{P}$ & $\mathrm{K}$ \\
\hline A1 & 8.00 & 1.90 & 53.77 & 6.04 & 195 \\
\hline $\mathrm{A} 2$ & 7.80 & 2.40 & 50.03 & 5.40 & 190 \\
\hline LSD $0.05 \mathrm{~A}$ & - & 0.05 & 1.72 & Ns & 0.73 \\
\hline $\mathrm{T} 1$ & 7.82 & 2.15 & 48.20 & 5.60 & 188 \\
\hline $\mathrm{T} 2$ & 7.85 & 2.36 & 51.44 & 5.85 & 192 \\
\hline $\mathrm{T} 3$ & 7.90 & 1.98 & 52.94 & 5.88 & 195 \\
\hline $\mathrm{T} 4$ & 7.92 & 2.27 & 54.50 & 5.96 & 196 \\
\hline $\mathrm{T} 5$ & 7.94 & 1.45 & 55.85 & 6.10 & 198 \\
\hline T6 & 7.96 & 2.18 & 58.10 & 6.22 & 200 \\
\hline LSD $0.05 \mathrm{~B}$ & - & 0.08 & 1.26 & Ns & 0.94 \\
\hline $\mathrm{A} 1 \mathrm{x} \mathrm{T} 1$ & 7.98 & 2.70 & 45.69 & 4.90 & 185 \\
\hline $\mathrm{A} 1 \mathrm{x} \mathrm{T} 2$ & 7.93 & 2.75 & 47.55 & 5.12 & 188 \\
\hline A1 x T3 & 7.96 & 2.16 & 48.50 & 5.23 & 190 \\
\hline $\mathrm{A} 1 \times \mathrm{T} 4$ & 7.95 & 2.30 & 49.88 & 5.45 & 194 \\
\hline A $1 \times 15$ & 7.94 & 1.70 & 50.65 & 5.56 & 195 \\
\hline A1 x T6 & 7.90 & 1.85 & 51.91 & 5.70 & 196 \\
\hline $\mathrm{A} 2 \mathrm{xT} 1$ & 8.02 & 2.50 & 52.70 & 5.95 & 198 \\
\hline $\mathrm{A} 2 \times \mathrm{T} 2$ & 7.93 & 2.55 & 55.47 & 5.97 & 199 \\
\hline $\mathrm{A} 2 \times \mathrm{T} 3$ & 8.00 & 2.35 & 57.07 & 5.98 & 199.5 \\
\hline $\mathrm{A} 2 \times \mathrm{T} 4$ & 7.87 & 2.28 & 57.50 & 6.02 & 200 \\
\hline $\mathrm{A} 2 \times \mathrm{T} 5$ & 7.98 & 2.85 & 59.80 & 6.04 & 202 \\
\hline A $2 \times \mathrm{T} 6$ & 7.88 & 2.62 & 62.10 & 6.10 & 205 \\
\hline LSD 0.05 A X B & - & 0.051 & 1.22 & Ns & 0.75 \\
\hline
\end{tabular}

fertilizers on the root growth, which consequently led to increasing the absorption of different nutrients. Abdel-Gwad et al. 2008, Sarhan and Ismail, 2003 found that the fodder beet has extremely high yield potential when grown on high fertile soils. Fodder beet requires large amounts of nitrogen, nitrogen fertilizers are one of the major costs for production of these crops. Shaban et al. (2014) found that the increase of nitrogen fertilizer rates led to increasing available $\mathrm{N}$ and $\mathrm{P}\left(\mathrm{mg} \mathrm{kg}^{-1}\right)$ in the soil. While applied bio-fertilizer can fix atmospheric nitrogen and solubilize phosphate. Also, Blumenthal, et. al, (1998) reported that the microorganisms contribute to nutrient availability in the soil and improve soil structure. Nitrogen is a vital element for plant growth as it is a component of protein. It is thus, essential for growth. Nitrogen is 
needed in greater amount than other elements and it is often the most limiting factor in crop production. Hence, application of nitrogen fertilizer results in higher biomass yield.

The effect of different mineral $N$ fertilizer rate and spacing of row on Chemical composition of fodder beet:

Chemical composition illustration (Table 4) showed that the spaces between rows led to increasing significantly values of crude protein, which were $12.66,10.72$, respectively compared with spacing raw 58 $\mathrm{cm}$ (A1) in leaves and roots, which were 12.08 and $9.42 \%$, respectively. The T6 $(120 \mathrm{~kg} / \mathrm{fed} \mathrm{N}+$ biofertilizer) recorded highest values of crude protein in leaves and roots. The highest crude protein contents are

Table (4): Effect of different row spacing and mineral nitrogen, Bio- fertilization on chemical composition of fodder beet for means of two seasons 2015-16 and 2016-17 (as dry matter basis)

\begin{tabular}{lccccccccccc}
\hline $\begin{array}{l}\text { Rate of } \\
\text { (kg/fed) B }\end{array}$ & \multicolumn{2}{c}{ CP\% } & \multicolumn{2}{c}{ CF\% } & \multicolumn{2}{c}{ EE\% } & & Ash\% & \multicolumn{2}{c}{$\begin{array}{c}\text { Nitrogen free } \\
\text { extract }\end{array}$} \\
\hline $\begin{array}{l}\text { Density of } \\
\text { row (cm)A }\end{array}$ & Leaves & Root & Leaves & Root & Leaves & Root & leaves & Root & Leaves & Root \\
\hline A1 & 12.08 & 9.42 & 24.07 & 6.7 & 2.38 & 3.17 & 10.96 & 9.1 & 50.51 & 71.61 \\
A2 & 12.66 & 10.72 & 24.25 & 8.04 & 2.53 & 3.4 & 10.99 & 9.63 & 49.57 & 68.21 \\
LSD 0.05 A & 0.111 & 0.045 & 0.045 & 0.064 & 0.045 & 0.045 & n.s & 0.31 & 0.12 & 0.05 \\
T1 & 11.03 & 8.67 & 25.23 & 8.01 & 2.42 & 3.18 & 10.68 & 8.43 & 50.64 & 71.71 \\
T2 & 10.86 & 8.96 & 24.58 & 7.95 & 2.43 & 3.13 & 9.41 & 8.77 & 52.72 & 71.19 \\
T3 & 11.73 & 9.62 & 23.96 & 6.98 & 2.41 & 3.15 & 10.82 & 8.75 & 51.08 & 71.5 \\
T4 & 12.46 & 10.02 & 24.11 & 7.6 & 2.44 & 3.22 & 11.09 & 9.2 & 49.9 & 69.96 \\
T5 & 13.17 & 10.24 & 23.11 & 5.98 & 2.49 & 3.22 & 11.63 & 9.7 & 49.6 & 70.86 \\
T6 & 14.99 & 12.91 & 23.95 & 7.7 & 2.58 & 3.83 & 12.24 & 11.33 & 46.24 & 64.23 \\
LSD 0.05 B & 0.148 & 0.17 & 0.166 & 0.14 & 0.076 & 0.09 & 0.232 & 0.45 & 0.101 & 0.09 \\
A1 x T1 & 10.6 & 7.7 & 24.54 & 7.33 & 2.27 & 3.04 & 10.18 & 8.27 & 52.41 & 73.66 \\
A1 x T2 & 10.68 & 8.51 & 24.5 & 7.45 & 2.39 & 3.09 & 10.17 & 8.88 & 52.26 & 72.07 \\
A1 x T3 & 11.65 & 9.09 & 24.12 & 6.51 & 2.33 & 3.11 & 10.82 & 8.54 & 51.08 & 72.75 \\
A1 x T4 & 11.94 & 9.72 & 24.36 & 7.18 & 2.37 & 3.19 & 10.98 & 9.15 & 50.35 & 70.76 \\
A1 x T5 & 12.53 & 10.25 & 22.53 & 5.46 & 2.39 & 3.15 & 11.33 & 9.44 & 51.22 & 71.7 \\
A1 x T6 & 14.87 & 11.22 & 24.34 & 6.24 & 2.56 & 3.43 & 12.27 & 10.31 & 45.96 & 68.8 \\
A2 xT1 & 11.46 & 9.64 & 25.92 & 9.15 & 2.58 & 3.32 & 11.17 & 8.6 & 48.87 & 69.29 \\
A2 x T2 & 11.03 & 9.41 & 24.66 & 8.44 & 2.46 & 3.16 & 8.64 & 8.66 & 53.21 & 70.33 \\
A2 x T3 & 11.8 & 10.14 & 23.79 & 7.44 & 2.48 & 3.19 & 10.81 & 8.95 & 51.12 & 70.28 \\
A2 x T4 & 12.98 & 10.31 & 23.86 & 8.01 & 2.5 & 3.25 & 11.19 & 9.24 & 49.47 & 69.19 \\
A2 x T5 & 13.8 & 10.22 & 23.68 & 6.5 & 2.58 & 3.28 & 11.94 & 9.96 & 48 & 70.04 \\
A2 x T6 & 15.11 & 14.59 & 23.56 & 8.68 & 2.59 & 4.22 & 12.2 & 12.35 & 46.54 & 60.16 \\
LSD 0.05 A & 0.209 & 0.25 & 0.235 & 0.19 & 0.108 & 0.13 & 0.328 & 0.63 & 0.143 & 0.12 \\
X B & & & & & & & & & & & \\
\hline
\end{tabular}

A1: $58 \mathrm{~cm}, \quad A 2: 76 \mathrm{~cm}, \quad T 1: 60 \mathrm{~kg} / \mathrm{fed} \mathrm{N}$ without bio-fertilizer, T2: 60kg/fed $\mathrm{N}$ with bio-fertilizer, $\quad T 3: 90 \mathrm{~kg} / \mathrm{fed} \mathrm{N}$ without bio-fertilizer, T4: $90 \mathrm{~kg} / \mathrm{fed} \mathrm{N}$ with bio-fertilizer, T5: $120 \mathrm{~kg} / \mathrm{fed} \mathrm{N}$ without bio-fertilizer and T6: $120 \mathrm{~kg} / \mathrm{fed}$ $N$ with bio-fertilizer.

obtained from 60, 90 and $120 \mathrm{~kg} / \mathrm{fed}$ nitrogen treatments $(11.03,11.73$ and 13.17) for leaves without biofertilizer and (10.86, 12.46 and $14.99 \%)$ for leaves with bio fertilizer, respectively, and 8.67, 9.62 and 10.24 $\%$ for roots without bio-fertilizer and 8.96, 10.02 and $12.91 \%$ for root with bio fertilizer, respectively. Effect of mineral $\mathrm{N}$ fertilizer and row spacing on fresh weight of shoot was not significant under increase of $\mathrm{N}$ rate and greater spacing, while dry shoot and root of fodder beet were significantly increased with increasing mineral nitrogen fertilizer Muna et al. (2011). Sarhan and Ismail (2003) found that root dry matter yield and crude protein yield of fodder beet were significant increased by increasing nitrogen fertilizer rate. 


\section{Ismail and Badr}

The crude fiber content is shown in Table (4). The highest significant increase values are obtained of density of row and leaves in (A2) $76 \mathrm{~cm}$ spaces between row $(24.25 \%)$ and roots $(8.04 \%)$ compared with spacing raw $58 \mathrm{~cm}$ (A1), which leaves and roots values are 24.07 and $6.70 \%$, respectively. The highest value on leaves and roots forage fodder beet in crude fiber are obtained from $60 \mathrm{~kg} / \mathrm{fed}$ nitrogen treatment without bio-fertilizer (T1), which values are 25.23 and 8.01, respectively. The effect of mineral nitrogen fertilizer and bio-fertilizer of row spaces on crude fiber are significant. As well as, the interaction between nitrogen fertilizers different rate alone or combined with bio-fertilizer and spacing row on crude fiber (\%) was significant. These results are in agreement with those obtained by Khogali et al. (2011) who showed that the applying of $120 \mathrm{~kg} \mathrm{~N} / \mathrm{ha}$ to fodder beet had significantly increased of crude fiber. Vladeta et al. (2012) found that the crude fiber content was increased significantly with increasing row spacing for all cultivars in both years.

The nitrogen free extract was increased in fodder beet with increasing mineral nitrogen fertilizer and wider row spacing with or without bio - fertilizer. Nitrogen free extract increased significantly with nitrogen fertilizer alone or combined with bio - fertilizer, also the space between rows were increased. Nitrogen free extract in leaves and roots are increased in $60 \mathrm{~kg} / \mathrm{fed} \mathrm{N}$ (A1), where the values were 50.51 and $71.61 \%$, respectively. The best results were recorded with $\mathrm{T} 1$ in leaves and roots without bio-fertilizer were 52.41 and $73.66 \%$, respectively. Finding results agree with those obtained by Hellal et al. (2011) who showed that the utilization chemical $\mathrm{N}$ fertilizer alone or combined with bio-fertilizers treatments alone led to increasing yield and carbohydrates. Abdel-Gwad et al. (2008) reported that the crude protein and ash of fodder beets were significantly increased by increasing nitrogen fertilizer level, while crude fibers and NFE take an opposite trend. Carbohydrates contents were about $71.69 \%$ in dry mater yield of fodder beets as reported by Abdallah and Yassen (2008). Fodder beets have high yield productivity when grown in fertile soil. The fodder beet requires high amount of nitrogen fertilizer by Albayrak and Camas (2007).

The effect of different mineral $N$ rates with or without bio-fertilizer and row spacing on gas parameters, short chain fatty acids and microbial protein by in-vitro gas production:

The data in Table (5) indicated insignificantly increase of Microbial protein (MP g/kg DOM), Gas production structure fractions (GPSF $\mathrm{ml} / \mathrm{g} \mathrm{DM}$ ), Gas production non structure fractions (GPNSF $\mathrm{ml} / \mathrm{g} \mathrm{DM}$ ), SCFA, s ( $\mathrm{mmol} / \mathrm{ml}$ gas) and gas production in (A2) $76 \mathrm{~cm}$ spaces between row compared with raw spacing $58 \mathrm{~cm}$ (A1) in leaves beet. The values are79.54, 5.14, 48.18 and 1.10 and 14.19, respectively. In the other hand, the beet roots had significantly higher regard in Microbial protein (MP g/kg DOM), Gas production structure fractions (GPSF $\mathrm{ml} / \mathrm{g} \mathrm{DM}$ ), SCFA, s (mmol /ml gas) and gas production (GP) for row spacing (A2) $76 \mathrm{~cm}$ compared with row spacing (A1) $58 \mathrm{~cm}$..

The treatment T6 (120 kg/fed N + bio-fertilizer) recorded the highest value SCFA, s (mmol /ml gas), Gas production nonstructural fractions (GPNSF ml/g DM) and Microbial protein (MP g/kg DOM) in leaves, the values are 1.18, 51.61and 82.30, while the root recorded highest value on treatment T5 $120 \mathrm{~kg} \mathrm{~N} / \mathrm{fed}$ without bio- fertilizer in SCFA, s ( $\mathrm{mmol} / \mathrm{ml}$ gas), Gas production nonstructural fractions GPNSF( $\mathrm{ml} / \mathrm{g}$ $\mathrm{DM}$ ) and Microbial protein (MP g/kg DOM) the values are $1.76,70.70$, and 104.30, respectively. The values of Gas production structure fractions (GPSF $\mathrm{ml} / \mathrm{g} \mathrm{DM}$ ) are increased non-significantly in leaves T2 but in roots are significantly increase, the values are 5.09 and $23.73(\mathrm{ml} / \mathrm{g} \mathrm{DM})$. The roots have an excellent feed quality and they are very palatable to ruminant stock. The leaf can be utilized if required to boost the total fodder output even further (Anonymous, 2006). Approximately $75 \%$ of fodder beet dry matter is in the root component (DAF (1998). The gas production of different classes of feed incubated in vitro in buffered rumen fluid was closely related to the production of SCFA, s which was based on carbohydrates fermentation (Kanak et al. 2012, Sallam et al. 2007 and Blummel and Oraskov 1993).

\section{The effect of different mineral $N$ rates with or without bio-fertilizer and row spacing nutritive values by in-vitro gas production:}

Data in Table (6) showed that the row density in (A2) $76 \mathrm{~cm}$ spaces between rows were insignificantly increased for IV-DMD\%, IV-DOM\% and IV- DCPI compared with raw spacing $58 \mathrm{~cm}$ (A1) in leaves. These values were increased from $37.96 \%, 64.29$, and $220.61 \mathrm{~g}$ /day spacing raw $58 \mathrm{~cm}$ (A1) to $44.18 \%, 66.28 \%$ and $233.26 \mathrm{~g} /$ day of row density (A2) $76 \mathrm{~cm}$ spaces, respectively, except IV-DOMI value1459.57g/day was significant increased, While the roots were significantly increased for IV-DOM\%, IV-DOMI and IV- DCPI, the values $81.79 \%, 3148.87 \mathrm{~g} /$ day and $346.31 \mathrm{~g} /$ day, but the value of IV-DMD\% insignificantly increased between the different spacing. 
Table (5): Effect of different mineral $\mathbf{N}$ rates with or without bio- fertilizer and row spacing on gas parameters, short chain fatty acids and microbial protein by in-vitro gas production.

\begin{tabular}{|c|c|c|c|c|c|c|c|c|c|c|}
\hline \multirow{2}{*}{$\begin{array}{l}\text { Rate of N } \\
\text { (kg/fed) B } \\
\text { Density of } \\
\text { row }(\mathrm{cm}) \mathrm{A}\end{array}$} & \multicolumn{2}{|c|}{$\begin{array}{l}\text { Microbial protein } \\
\text { g/kg DOM }\end{array}$} & \multicolumn{2}{|c|}{$\begin{array}{c}\text { GPSF } \\
\mathrm{ml} / \mathrm{g} \mathrm{DM}\end{array}$} & \multicolumn{2}{|c|}{$\begin{array}{c}\text { GPNSF } \\
\mathrm{ml} / \mathrm{g} \mathrm{DM}\end{array}$} & \multicolumn{2}{|c|}{$\begin{array}{c}\text { SCFA, s } \\
\mathrm{mmol} / \mathrm{ml} \text { gas }\end{array}$} & \multicolumn{2}{|c|}{$\begin{array}{c}\text { GP } \\
\mathrm{ml} / 200 \mathrm{mgDM}\end{array}$} \\
\hline & Leaves & Root & Leaves & Root & leaves & Root & Leaves & Root & Leaves & Root \\
\hline A1 & 77.15 & 92.80 & 3.46 & 16.55 & 46.53 & 57.73 & 1.04 & 1.46 & 11.35 & 29.04 \\
\hline A2 & 79.54 & 98.14 & 5.14 & 20.27 & 48.18 & 61.97 & 1.10 & 1.60 & 14.19 & 31.95 \\
\hline LSD $0.05 \mathrm{~A}$ & n.s & 1.84 & n.s & 3.18 & n.s & 3.59 & n.s & 0.05 & n.s & 2.0 \\
\hline $\mathrm{T} 1$ & 78.27 & 96.45 & 4.59 & 19.44 & 46.18 & 58.38 & 1.07 & 1.55 & 12.10 & 32.59 \\
\hline $\mathrm{T} 2$ & 76.95 & 91.80 & 5.09 & 23.73 & 46.87 & 53.03 & 1.03 & 1.43 & 11.53 & 28.18 \\
\hline T3 & 79.73 & 88.79 & 4.84 & 12.68 & 48.48 & 56.55 & 1.11 & 1.35 & 14.72 & 24.76 \\
\hline $\mathrm{T} 4$ & 73.23 & 93.76 & 2.69 & 23.07 & 43.00 & 57.44 & 0.93 & 1.48 & 7.46 & 30.25 \\
\hline T5 & 79.58 & 104.30 & 4.84 & 14.99 & 47.97 & 70.70 & 1.10 & 1.76 & 14.35 & 42.12 \\
\hline T6 & 82.30 & 97.71 & 3.77 & 16.55 & 51.61 & 63.00 & 1.18 & 1.59 & 16.46 & 33.78 \\
\hline LSD $0.05 \mathrm{~B}$ & 2.81 & 3.74 & n.s & 7.78 & 4.58 & 6.89 & 0.07 & 0.11 & 3.10 & 4.19 \\
\hline A1 x T1 & 76.07 & 94.50 & 4.10 & 14.66 & 45.66 & 60.84 & 1.01 & 1.50 & 10.44 & 31.46 \\
\hline A1 x T2 & 74.60 & 92.08 & 5.09 & 19.94 & 44.32 & 55.50 & 0.97 & 1.44 & 8.81 & 28.50 \\
\hline A $1 \times$ T3 & 77.04 & 76.02 & 2.61 & 14.92 & 47.16 & 46.53 & 1.04 & 1.01 & 11.68 & 10.66 \\
\hline A1 x T4 & 74.28 & 93.98 & 1.62 & 22.58 & 44.08 & 58.28 & 0.96 & 1.09 & 8.47 & 30.53 \\
\hline A $1 \times$ T5 & 77.80 & 103.09 & 2.94 & 16.64 & 47.51 & 67.68 & 1.06 & 1.73 & 12.38 & 40.79 \\
\hline A1 x T6 & 81.50 & 97.12 & 4.43 & 20.60 & 50.43 & 57.56 & 1.16 & 1.57 & 16.34 & 32.32 \\
\hline A 2 xT1 & 80.48 & 98.39 & 5.09 & 24.23 & 46.70 & 55.93 & 1.13 & 1.61 & 13.75 & 33.72 \\
\hline A $2 \times$ T2 & 79.31 & 91.53 & 7.07 & 27.53 & 49.42 & 50.56 & 1.10 & 1.42 & 14.25 & 27.87 \\
\hline A $2 \times \mathrm{T} 3$ & 82.42 & 101.57 & 5.09 & 20.43 & 49.80 & 66.56 & 1.18 & 1.69 & 17.77 & 38.86 \\
\hline $\mathrm{A} 2 \times \mathrm{T} 4$ & 72.18 & 93.55 & 3.77 & 23.57 & 41.92 & 56.60 & 0.91 & 1.48 & 6.44 & 29.97 \\
\hline A2 $\times$ T5 & 81.35 & 105.51 & 6.74 & 13.34 & 48.44 & 73.73 & 1.15 & 1.80 & 16.31 & 43.46 \\
\hline A $2 \times$ T6 & 83.10 & 98.31 & 3.11 & 12.51 & 52.78 & 68.44 & 1.20 & 1.60 & 16.58 & 32.24 \\
\hline $\begin{array}{l}\text { LSD } 0.05 \text { A } \\
\text { X B }\end{array}$ & 3.97 & 5.29 & n.s & 11.01 & n.s & 9.75 & 0.11 & 0.14 & n.s & 5.92 \\
\hline
\end{tabular}

The effect of nitrogen fertilization treatment with or without bio- fertilizer on digestibility value in Sixth treatment. The treatment T6 (120 kg/fed N + bio-fertilizer) had recorded highest values of IV-DOM\% and IV-DOMI in leaves except IV-DMD and IV-DCPI were insignificantly increased with T1, while the roots where recorded the highest value on treatment T5 $(120 \mathrm{~kg} \mathrm{~N} /$ fed without bio- fertilizer) in IV-DOM, IVDOMI and IV-DCPI of row density in (A2) $76 \mathrm{~cm}$ spaces except IV-DMD\% were recorded high value $63.37 \%$ with T1 (60 kg N/fed without bio- fertilizer). Kaur et al. (2011) reported rapid rates of CP degradation $0.21 / \mathrm{hr}$. for rape leaf, though in the current study the low values observed may reflect the low $\mathrm{CP}$ values of the forage 14 to $11 \% \mathrm{CP}$ and the associated difficulties with microbial colonization of incubated residue.

The interaction between row density $\mathrm{cm}$ and nitrogen (with and without biofertilizer the best results recorded with T6 (120 kg/fed N with bio- fertilizer) in the leaves with IV-DMD\%, GP(ml/200mg DM) and IV-DOM\% but in the roots the best results recorded with treatment T5 $(120 \mathrm{~kg} / \mathrm{fed} \mathrm{N})$ except with IVDMD\% recorded with T1 $(60 \mathrm{~kg} / \mathrm{fed} \mathrm{N})$ Fodder beet is highly digestible: IV-OMD\% is in the $87-90 \%$ range( Dulphy et al., 2000), although a value of $96 \%$ has been reported (Sabri et al.,1988). Adequate balance of $\mathrm{N}$ to $\mathrm{OM}$ available in the rumen has the potential to improve microbial protein synthesis and increase metabolizable protein supply to the ruminant. Increasingly farmers are adopting low $\mathrm{N}$ feeding systems, to the point where diets offered during the winter may have less than 12\% CP. Zamfir et al. (2001) and Zaki (1999) reported that increasing nitrogen fertilization led to increasing dry matter yield and crude protein content of fodder beet. Previous studies with fodder beet indicated that the nitrogen rates influenced root yield and yield components (Yüksel et al. 2009, Prokopenko et al. 1997, Geweifel and Aly 1996 and Karczmarczyk et al. 1995). 
Table (6): Effect of different mineral $N$ rates with or without bio- fertilizer and row spacing nutritive values by in-vitro gas production.

\begin{tabular}{|c|c|c|c|c|c|c|c|c|}
\hline \multirow{2}{*}{$\begin{array}{l}\text { Rate of } \mathrm{N} \\
(\mathrm{kg} / \mathrm{fed}) \mathrm{B} \\
\text { Density of row }(\mathrm{cm}) \\
\text { A }\end{array}$} & \multicolumn{2}{|c|}{ IV-DMD\% } & \multicolumn{2}{|c|}{ IV-DOM\% } & \multicolumn{2}{|c|}{ IV-DOMI (g/day) } & \multicolumn{2}{|c|}{ IV-DCPI (g/day) } \\
\hline & leaves & Root & Leaves & Root & Leaves & Root & Leaves & Root \\
\hline A1 & 37.96 & 47.74 & 64.29 & 77.33 & 1459.57 & 2768.27 & 220.61 & 534.26 \\
\hline $\mathrm{A} 2$ & 44.18 & 46.94 & 66.28 & 81.79 & 1676.24 & 3148.87 & 233.36 & 346.31 \\
\hline LSD $0.05 \mathrm{~A}$ & n.s & n.s & n.s & 1.53 & 186.42 & 170.01 & n.s & 34.63 \\
\hline $\mathrm{T} 1$ & 35.46 & 63.37 & 65.23 & 80.37 & 1532.43 & 2940.67 & 213.72 & 481.24 \\
\hline $\mathrm{T} 2$ & 39.82 & 48.82 & 64.13 & 76.50 & 1563.99 & 2826.06 & 239.32 & 499.78 \\
\hline $\mathrm{T} 3$ & 45.32 & 35.04 & 66.44 & 73.99 & 1724.31 & 2449.89 & 211.14 & 422.91 \\
\hline $\mathrm{T} 4$ & 38.52 & 37.00 & 61.03 & 78.14 & 1196.00 & 3121.60 & 197.02 & 489.46 \\
\hline T5 & 40.60 & 45.91 & 66.31 & 86.92 & 1619.68 & 3356.64 & 242.27 & 553.03 \\
\hline T6 & 46.67 & 53.90 & 68.59 & 81.43 & 1771.00 & 3056.57 & 258.44 & 485.08 \\
\hline LSD $0.05 \mathrm{~B}$ & n.s & 5.81 & 2.34 & 3.12 & 156.22 & 232.14 & n.s & 73.58 \\
\hline $\mathrm{A} 1 \times \mathrm{T} 1$ & 27.20 & 65.82 & 63.39 & 78.75 & 1471.90 & 2809.96 & 207.26 & 461.30 \\
\hline $\mathrm{A} 1 \times \mathrm{T} 2$ & 37.97 & 46.90 & 62.16 & 76.73 & 1403.66 & 2900.09 & 227.32 & 419.64 \\
\hline $\mathrm{A} 1 \times \mathrm{T} 3$ & 40.54 & 38.60 & 64.20 & 63.35 & 1462.89 & 1490.99 & 211.42 & 270.99 \\
\hline $\mathrm{A} 1 \times \mathrm{T} 4$ & 46.06 & 35.55 & 61.90 & 78.32 & 1184.73 & 3126.76 & 202.23 & 498.56 \\
\hline A1 x T5 & 38.84 & 44.77 & 64.84 & 85.91 & 1482.21 & 3295.46 & 225.45 & 535.38 \\
\hline A 1 x T6 & 37.12 & 54.83 & 67.92 & 80.93 & 1752.00 & 2986.38 & 250.00 & 471.60 \\
\hline A 2 xT1 & 43.73 & 60.91 & 67.06 & 81.99 & 1592.96 & 3071.38 & 220.19 & 501.19 \\
\hline $\mathrm{A} 2 \times \mathrm{T} 2$ & 41.67 & 50.74 & 66.09 & 76.27 & 1724.32 & 2752,04 & 251.31 & 570.68 \\
\hline A $2 \times \mathrm{T} 3$ & 50.10 & 31.48 & 68.68 & 84.64 & 1790.00 & 3408.80 & 210.85 & 574.84 \\
\hline $\mathrm{A} 2 \times \mathrm{T} 4$ & 30.99 & 38.46 & 60.15 & 77.96 & 1207.26 & 3116.45 & 191.81 & 480.36 \\
\hline A $2 \times \mathrm{T} 5$ & 42.37 & 47.05 & 67.79 & 87.93 & 1757.16 & 3417.81 & 259.10 & 579.91 \\
\hline A $2 \times$ T6 & 56.22 & 52.98 & 69.25 & 81.92 & 1985.72 & 3126.76 & 266.88 & 498.56 \\
\hline LSD 0.05 A X B & n.s & n.s & 3.31 & 4. 41 & 220.93 & 328.30 & n.s & 104.06 \\
\hline
\end{tabular}

\section{Effect of different mineral $N$ rates with or without bio-fertilizer and row spacing on energy parameters by in-vitro gas production:}

Data in Table (7) showed that the row density in (A2) $76 \mathrm{~cm}$ spaces between rows led to increasing insignificantly in ME (MJ/kg DM), NE M cal./Lb. DM and NEL MJ $/ \mathrm{kg}$ DM compared with raw spacing 58 $\mathrm{cm}$ (A1) in leaves. These values were increased from 7.86, 3.22 and 4.35 in (A1) to 8.23, 3.36 and 4.79 $(\mathrm{MJ} / \mathrm{kg} \mathrm{DM})$ in (A2) $76 \mathrm{~cm}$ spaces, While readerly the roots were significantly increased in $\mathrm{ME}(\mathrm{MJ} / \mathrm{kg}$ $\mathrm{DM})$, NE M cal./Lb. DM and NEL MJ $/ \mathrm{kg} \mathrm{DM}$ from 10.20, 3.59 and $77.33 \%$ and 6.19 in raw spacing $58 \mathrm{~cm}$ (A1) to $11.02,3.80$ and 6.77 row density in (A2) $76 \mathrm{~cm}$ spaces, respectively.

The treatment T6 $(120 \mathrm{~kg} / \mathrm{fed} \mathrm{N}+$ bio-fertilizer $)$ recorded highest significant value in leaves, the values are 8.67, 3.54 and 5.09, respectively. While the root where recorded highest significant value on treatment T5 $(120 \mathrm{~kg} \mathrm{~N} /$ fed without bio- fertilizer) in ME (MJ/kg DM), NE M cal./Lb. DM and NEL MJ $/ \mathrm{kg} \mathrm{DM,} \mathrm{the}$ values were $11.59,3.99$ and 7.43 , respectively. The interaction between row density $\mathrm{cm}$ and nitrogen (with and without biofertilizer the best results recorded with T6 $(120 \mathrm{~kg} / \mathrm{fed} \mathrm{N}$ with bio- fertilizer) in the leaves with ME (MJ/kg DM), NE M cal./Lb. DM and NEL MJ $/ \mathrm{kg}$ DM, but recorded these results the highest significant with treatment T5 $(120 \mathrm{~kg} / \mathrm{fed} \mathrm{N})$ in the roots. The high sugar content makes fodder beet palatable and a valuable energy source (Draycott et al. (2003). Henry (2010) found that the conversion efficiency of gross energy in milk and meat net energy were 48 and 52\%, respectively. This is due to the low content in CP from the fodder beet samples analyzed. These crops are used because they are high yielding and typically have high metabolizable energy (ME) content of over $12 \mathrm{MJ} / \mathrm{kg}(\mathrm{DM})$, even at advanced stages of maturity (Judson and Edwards 2008). 
Table (7): Effect of different mineral $N$ rates with or without bio- fertilizer and row spacing on energy parameters by in-vitro gas production.

\begin{tabular}{|c|c|c|c|c|c|c|}
\hline \multirow{2}{*}{$\begin{array}{l}\text { Rate of } \mathrm{N} \\
\text { (kg/fed) B } \\
\text { Density of row }(\mathrm{cm}) \mathrm{A}\end{array}$} & \multicolumn{2}{|c|}{ ME (MJ /kg DM) } & \multicolumn{2}{|c|}{ NE (M cal./Lb. DM) } & \multicolumn{2}{|c|}{ NEL (MJ /kg DM) } \\
\hline & Leaves & Root & Leaves & Root & Leaves & Root \\
\hline A1 & 7.86 & 10.20 & 3.22 & 3.59 & 4.53 & 6.19 \\
\hline A2 & 8.23 & 11.02 & 3.36 & 3.80 & 4.79 & 6.77 \\
\hline LSD $0.05 \mathrm{~A}$ & n.s & 0.28 & n.s & 0.05 & n.s & 0.20 \\
\hline $\mathrm{T} 1$ & 8.02 & 10.75 & 3.20 & 3.62 & 4.64 & 6.58 \\
\hline $\mathrm{T} 2$ & 7.82 & 10.05 & 3.18 & 3.54 & 4.50 & 6.08 \\
\hline T3 & 8.24 & 9.61 & 3.29 & 3.56 & 4.80 & 5.77 \\
\hline $\mathrm{T} 4$ & 7.27 & 10.36 & 3.14 & 3.66 & 4.11 & 6.30 \\
\hline T5 & 8.24 & 11.95 & 3.40 & 3.99 & 4.80 & 7.43 \\
\hline T6 & 8.67 & 10.96 & 3.54 & 3.79 & 5.09 & 6.72 \\
\hline LSD 0.05 B & 0.40 & 0.57 & 0.08 & 0.11 & 0.30 & 0.40 \\
\hline $\mathrm{A} 1 \times \mathrm{T} 1$ & 7.68 & 10.45 & 3.15 & 3.55 & 4.41 & 6.36 \\
\hline A1 x T2 & 7.46 & 10.09 & 3.09 & 3.53 & 4.25 & 6.11 \\
\hline A1 x T3 & 7.83 & 7.66 & 3.17 & 3.09 & 4.51 & 4.40 \\
\hline A1 x T4 & 7.41 & 10.38 & 3.11 & 3.65 & 4.22 & 6.32 \\
\hline A1 x T5 & 7.97 & 11.77 & 3.32 & 3.96 & 4.60 & 7.30 \\
\hline A1 x T6 & 8.56 & 10.87 & 3.51 & 3.74 & 5.01 & 6.66 \\
\hline A2 xT1 & 8.35 & 11.05 & 3.26 & 3.68 & 4.88 & 6.79 \\
\hline A $2 \times \mathrm{T} 2$ & 8.18 & 10.01 & 3.27 & 3.55 & 4.75 & 6.05 \\
\hline A $2 \times \mathrm{T} 3$ & 8.65 & 11.57 & 3.41 & 4.03 & 5.09 & 7.15 \\
\hline A $2 \times \mathrm{T} 4$ & 7.12 & 10.33 & 3.17 & 3.68 & 4.00 & 6.28 \\
\hline A $2 \times$ T5 & 8.52 & 12.14 & 3.49 & 4.03 & 4.99 & 7.56 \\
\hline A2 x T6 & 8.79 & 11.05 & 3.57 & 3.84 & 5.18 & 6.79 \\
\hline LSD 0.05 A X B & 0.60 & 0.80 & n.s & 0.16 & 0.42 & 0.57 \\
\hline
\end{tabular}

\section{CONCLUSIONS}

Nitrogen fertilization had significant positive effects on growth of fodder beet, root diameter and root length. The highest growth was associated with $(90 \mathrm{~kg} / \mathrm{fed}$ nitrogen + bio-fertilization). So, the optimum dose under new agriculture spacing harvest can be used. Root yield and quality changed with spacing harvest. Increasing $\mathrm{N}$ rates resulted in increased root yield of fodder beet. The highest root crude protein and minerals were obtained with the $120 \mathrm{~kg} / \mathrm{fed}$ nitrogen rate. There was a trend to increase at a wider plant space. The results of $120 \mathrm{~kg}$ per fed nitrogen treatments and spacing $76 \mathrm{~cm}$ can led to recommending for similar ecological conditions. The increasing microbial population in rhizosphere of root led to effect on transforming inorganic substances. The highest crude protein contents are obtained of row in (A2) $76 \mathrm{~cm}$ spaces. The highest increasing values crude protein, crude protein, ether extract contents(MP g/kg DOM), Gas production structure fractions (GPSF $\mathrm{ml} / \mathrm{g} \mathrm{DM}$ ), Gas production non structure fractions (GPNSF $\mathrm{ml} / \mathrm{g}$ DM), SCFA, s ( mmol /ml gas), gas production IV-DMD\%, IV-DOM\%, IV- DCPI, ME (MJ/kg DM), NE $\mathrm{M}$ cal./Lb. DM and NEL MJ $/ \mathrm{kg}$ DM were obtained of row in (A2) $76 \mathrm{~cm}$ spaces compared with raw spacing $58 \mathrm{~cm}$ (A1) in leaves and roots. The best treatment recorded with T6. T6 $(120 \mathrm{~kg} / \mathrm{fed} \mathrm{N}+$ biofertilizer) recorded the highest values of crude protein and ether extract in leaves and roots. T6 $(120 \mathrm{~kg} / \mathrm{fed} \mathrm{N}$ + bio-fertilizer) recorded the highest values of SCFA, s (mmol /ml gas), Gas production nonstructural fractions (GPNSF ml/g DM), Microbial protein (MP g/kg DOM), IV-DMD, IV-DOM\%, IV-DOMI and IVDCPI, ME (MJ/kg DM), NE M cal./Lb. DM and NEL MJ $/ \mathrm{kg}$ DM in leaves compared with other treatments. Readily the root where recorded the highest value on treatment T5 $(120 \mathrm{~kg} \mathrm{~N} /$ fed without bio- fertilizer) in SCFA, s (mmol /ml gas), Gas production nonstructural fractions GPNSF( ml/g DM), Microbial protein 


\section{Ismail and Badr}

(MPg /kg DOM), IV-DOM\%, IV-DOMI, IV- DCPI, ME (MJ/kg DM), NE Mcal./Lb. DM and NEL MJ $/ \mathrm{kg}$

DM compared with the other treatments.

\section{REFERENCES}

Abdallah, E.F. and A.A. Yassen (2008). Fodder beet productivity under fertilization treatments and water augmentation. Australian journal of Basic and Applied Sciences, 2 (2): 282-287.

Abd El-Ghany, B. F.; A. M. R. Arafa; T. A. El-Rahmany and M. M. El-Shazly (2010). Effect of some microorganisms on soil properties and wheat production under North Sinsi Condition. J. of Appl. Sci. Res. 4 (5): 559- 579.

Abdel-Gwad, M.S.A.; T.K. A. El-Aziz and M. A. A El-Galil (2008). Effect of intercropping wheat with fodder beet under different levels of $\mathrm{N}$-application on yield and quality. Annals of Agricultural Science (Cairo). 53 (2): 353-362.

Abo EL-Goud, S.M.M. (2000). Agronomic studies on fodder beet. Ph. D. Thesis, Fac. of Agric. Mansoura Univ. Egypt.

Albayrak, S. and N. Camas (2007). Effects of Temperature and Light Intensity on Growth of Fodder Beet (Beta vulgaris var. crassa Mansf.). Bangladesh J. Bot., 36 (1): 1-12.

AOAC (2000) Official Methods of Analysis, 15th end. Association of Official Analytical Chemists. Washington DC, USA.

Amin, G. A.; A. B Elham and M.H.M. Afifi (2013) Root yield and quality of sugar beet (Beta vulgaris L.) in response to biofertilizer and foliar application with micronutrients. World Appl. Sci. J. 27 (11): 13851389.

Anonymous (2006). Fodder beet. http://www seed2 grow co. uk / catalog/ Fodder Beet Seed. Html. (16.01.2006).

Bahman, J.; G. Reza; Z.F. Ahmad and R.G. Ali (2013). Impact of crop density and soil fertilization on sugar beet. Inter. J. of Agric. And Crop. Sci. 5 (24): 2991- 2999.

Blumenthal '"jurg; M., Baltensperger; D. David; Cassman, Kenneth G Mason; C. Stephen and DAF (Department of Agriculture and Food), (1998). Root, fodder crop, pulse and oilseed varieties. Fresh recommended list. Government Stationary Office. Dublin, $17 \mathrm{p}$.

Blummel, M. and E.R. Orskov (1993). Comparison of gas production and nylon bag degradability of roughages in predictions feed intake in cattle. Anim. Feed Sci. Techno, 40:109.

Chapman, H.D. and P.E. Pratt (1961). Methods of Analysis of Soils, Plants and Waters, University of California, Division of Agricultural Science: Los Angeles, pp. 60- 61, 159-179.

Chumpawadee S, K. Sommart; T. Vongpralub and V. Pattarajinda (2005). Nutritional evaluation of nonforage high fibrous tropical feeds for ruminant using in vitro gas production technique. Pak. J. Nutr. 4: 298-303.

Gomez, K.A. and Gomez, A.A. (1984). Statistical Procedures for Agri. Res., 2nd ed., Wiley, New York.

Cottenie, M.; L.Verloo; G. Kieken Velgh and R. Camcrlynck (1982). Chemical Analysis of Plant and Soil. Lab. Anal. Agro. Chem., State Univ., Ghent, Belgium.

Czerkawski, J. W. (1986). An introduction to rumen studies. Pergamon (Book.).

DAF (Department of Agriculture and Food), (1998). Root, fodder crop, pulse and oilseed varieties. Frish recommended list. Government Stationary Office. Dublin, 17 p.

Draycott, A. P. and D. R. Christenson (2003). Nutrients for sugar beet production: Soil-Plant relationships. CAB International, Wallingford, UK

Dulphy, J. P.; C. Demarquilly (2000). Fodder beets in animal husbandry. Fourrages, 163: 307-314 
Judson, H.G. and G.R. Edwards (2008). Survey of management practices of dairy cows grazing kale in Canterbury. Proceeidngs of the New Zealand Grassland Association. 70, 249-254.

Halga, P.; Pop, Avarvarei, Teona; Popa, Viorica (2005). Nutriţie animală, Ed. Alfa, Iaşi.

Hellal, F.A.; S.A. Mahfouz and F.A.S. Hassan (2011). Partial substitution of mineral nitrogen fertilizer by biofertilizer on (Anethum graveolens L.). Plant Agric. Biol. J. N. Am. 2 (4): 652- 660.

Henry, K., (2010). Fodder Beet. In: Bradshaw, J. E. Handbook of plant breeding, vol 7

Getachew, G.; P.H. Robinson; E.J. De-Peters; S.J. Taylor (2004). Relationships between chemical composition, dry matter degradation and in vitro gas production of several ruminant feeds. Anim. Feed Sci. Technol. 111: 57-71.

Geweifel, H.G.M and R.M. Aly (1996). Effect of nitrogen and potassium fertilization treatments on growth, yield and quality of some fodder beet varieties. Annals of Agric. Sci, Moshtohor 34(2): 441-454.

Kamalak, A., and O. Canbolat (2010). Determination of nutritive value of wild narrow-leaved clover (Trifolium angustifolium) hay harvested at three maturity stages using chemical composition and in vitro gas production. Trop. Grassland, 44: 128-133.

Kanak, A.R.; M.J. Khan; M.R. Debi; M.K. Pikar and M. Aktar (2012). Nutritive value of three fodder species at different stages of maturity. Bangladesh Journal of Animal Science.

Kandil, A.A.; M.A. Badawi; S.A. El-Moursy and U.M. Abdou (2004). Effect of planting dates, nitrogen levels and biofertilization treatments on 1: Growth attributes of sugar beet. Scientific J. of King Faisl Univ. 5 (2): 227- 237.

Karczmarczyk, S.; Z. Koszanski; M. Roy and D. Sciazko (1995). Effect of sprinkler irrigation and nitrogen fertilizer application on sugar and fodder beets cultivated on a good rye complex soil. II. Chemical composition of the crop. Zeszyty Naukowe Akademii Rolniczej w Szczecinie, Rolnictwo 59: 65-72.

Kaur, R; S.C. Garcia; W.J. Fulkerson; I.M. Barchia (2011). Degradation kinetics of leaves, petioles and stems of forage rape (Brassica napus) as affected by maturity. Animal Feed Science and Technology. $168,165-178$.

Khogali, M.E.; Y.M. Ibrahim and M.G. El-Hag (2012). Effect of nitrogen and spacing on growth of fodder beet (Beta vulgaris L. var. Crassa) cultivars under Sudan conditions. J. of Pharmaceutical and Scientific Innovation. 1 (3): 67- 71.

Khogali, M.E.; M.D. Yassin and G.E. Mahgoub (2011). Productivity of fodder beet (Beta vugaris var. Crassa) cultivars affected by nitrogen and plant spacing. Agric. Biol. J. North. Am. 2 (5): 791- 798.

Ibrahim, Y.M. (2005). Ranges and forage (In Arabic). Dar Azza for publication, Khartoum, Sudan; p. 300.

INRA (2007). Alimentation des bovins, ovins et caprins. Besoins des animaux - valeurs des aliments. Tables Inra 2007. Quae éditions

Judson, H.G. and G.R. Edwards (2008). Survey of management practices of dairy cows grazing kale in Canterbury. Proceeidngs of the New Zealand Grassland Association. 70, 249-254.

Maheri -Sis N; M. Chamani; A.A. Sadeghi; A. Mirza-Aghazadeh and A. Aghajanzadeh-Golshani (2008). Nutritional evaluation of kabuli and desi type chickpeas ((Cicer arietinum L.) for ruminants using in vitro gas production technique. Afr. J. Biotech. 7: 2946-2951.

Maheri-Sis N; M. Chamani; A.A. Sadeghi; A. Mirza-Aghazadeh and A.A. Safaei (2007). Nutritional evaluation of chickpeas waste for ruminants using in vitro gas production technique. J. Anim. Vet. Adv. 6:1453-1457.

Menke, K.H. and H. Steingass (1988). Estimation of energetic feed value obtain from chemical analysis and in vitro gas production using rumen fluid Anim. Res. Dev. 28: 7-55.

Menke, KH; L. Raab; A. Salewski; H. Steingass; D. Fritz and W. Schneider (1979). The estimation of digestibility and metabolizable energy content of ruminant feedstuffs from the gas production when they incubated with rumen liquor in vitro. J. Agric. Sci. 92: 217-222. 


\section{Ismail and Badr}

Muna, E. Kh.; M. I. D. Yassin and G. E. Mahgoub, (2011). Productivity of fodder beet (Beta vulgaris var. Crassa) cultivars affected by nitrogen and plant spacing. Agric. And Biology. J. of North America. 2(5): 791- 798.

Mustafa, M. El. (2007). Effect of nitrogen and phosphorus fertilization on the performance of three sugar beet (Beta vulgaris L.) cultivars. M. Sc. Thesis, Faculty of Agriculture, University of Khartoum, Sudan.

Page, C.A.; D.D. Evans; J. L.White; L.E. Ensiminger and F.E. Clark (1982). Methods of Soil Analysis. Amer. Soc. Agron. Inc., Ser. 9 in Agron. Madison, Wisconsin.

Prokopenko, L.S., R.V. Olonicheva and I.F. Pidpalii (1997). Amino acid composition and protein nutritive value of fodder beet. Visnik Agrarnoi Nauki 1: 26-28.

Ramadan, A.; H. Mohamed and A. Saad (2013). Effect of soil amendment with yeasts as bio-fertilizers on the growth and productivity of sugar beet. African J. of Agric. Res. 8 (1): 46- 56.

Roy, P. R. S. and Z. H. Khandaker (2010) Effect of phosphorus fertilizer on yield and nutritional value of sorghum (Sorghum bicolor L.) fodder at three cuttings. Bang. J. Anim. Sci., 39(1\&2): 106 - 115

Sabri, M. S.; Offer, N. W.; D. J. Roberts 1988. A note on the apparent digestibility of fodder beet roots in sheep. Anim. Prod., 47: 509-511

Sallam S.M. A.; M.E.A. Nasser; A.M. El-waziry; F.C.S. Bueno and A.L. Abdallah (2007). Yeast of yam in vitro rumen gas production technique to evaluate some ruminant feedstuffs. Appl.Sci.Res.,3(1):34-41

Sarhan, G.M.A. and S.A. Ismail (2003). Response of fodder beet (Beta vulgaris L.) to different sources and levels of nitrogen fewer than two levels of potassium fertilization. Annals of Agricultural Science, Moshtohor . 41 (1): 461-473.

Shaban, Kh. A.; E. M. Abd El-Fatah and D. A. Syed (2014). Impact on humic acid and mineral nitrogen fertilization on soil chemical properties and yield and quality of sugar beet under saline soil. J. Soil Sci. and Agric. Eng. Mansoura Univ. 5 (10): 1317- 1335.

Shaban Kh. A. and M. N. A. Omar. (2006). Improvement of maize yield and some soil properties by using nitrogen mineral and PGPR group fertilization in newly cultivated saline soils. Egypt. J. Soil. Sci. 46 (3): 329- 342.

Siam, H.S.; A. Sh. Khaled and S.A. Mohamoud (2013). Evaluation of applying different mineral nitrogen sources on soil fertility and wheat productivity under saline soil conditions. J. of Appl. Sci. Res. 9 (4): 3146- 3156.

Van Gelder M.H.; M.A.M. Rodrigues; J.L. De Boever; H. Den Hartigh; C. Rymer; M. van Oostrum; R. van Kaahthoven; J.W. Cone (2005). Ranking of in vitro fermentability of 20 feedstuffs with an automated gas production technique: Results of a ring test. Anim. Feed Sci. Technol. 123-124: 243-253.

Vessey, J.K. (2003). Plant growth promoting rhizobacteria as biofertilizers. Plant Soil 255:571-586.

Vladeta, S.; S. Rade; D. Dragan and D. Djuroyic (2012). Effect of row spacing on seed and forage yield in sainfoin (Onobrychis viciifolia Scop.) cultivars. Turk. J. Africa. For. 36: 35-44.

Wu, S.C.; Y.M. Luo; K.C. Cheung and M.H. Wong (2006). Influence of bacteria on Pb and $\mathrm{Zn}$ speciation, mobility and bioavailability in soil. Environmental Pollution, 144 (3): 765 - 773.

Zamfir, I.; M.C. Zamfir; A. Dihoru and E. Dumitru (2001). The long-term fertilization influence on both fodder beet yield and some features of argilluvial chernozem from Burnas plain. Analele Instiutului de Cercetari pentru Cereale si Plante Tehnice, Fundulea 68: 289- 299.

Zaki, N.M. (1999). Growth and yield responses of fodder beet (Beta vulgaris L.) to application methods for and potassium fertilizers. Annals of Agric. Sci, Moshtohor 37(4): 2179-2193. J. of Food, nitrogen Agric. \& Envir., Vol.7 (3\&4), July-October 2009339.

Yüksel, O.; S ve Albayrak and M.Türk (2009). Yemli pancar (Beta vulgaris var. crass Mansf.) çe_itlerinin Isparta koullarına adaptasyonu. Türkiye VIII. Tarla Bit. Kong. 761-764. Hatay. 


\title{
تأثثير التسميد النتروجينى والحيوي مع اختلاف مسافات الزراعة فى تحسين نمو و جودة محصول بنجر العلف

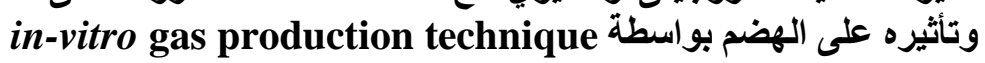

\author{
فاطمه شهاب الدين احمد1 و عزة محمد محمد بدر2 \\ 1 قسم بحوث العلف .معهل المحاصيل العقلية- ـ مركز البحوث الزراعية ـ الجبيزة - مصر. \\ 2 المركز الاقليسى للاغذية والاعلاف ـ مركز البحوث النزراعية ـ الجبزة. مصر.
}

\begin{abstract}
الهدف من الدراسة معرفة اثير استخدام المعدلات المختلفة من السماد النيتروجينى المعدنى مع او بدون الاسمدة الحيوية و استخدام

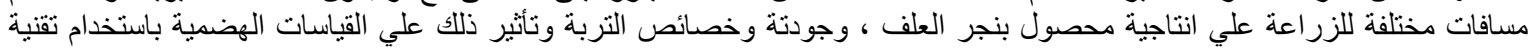

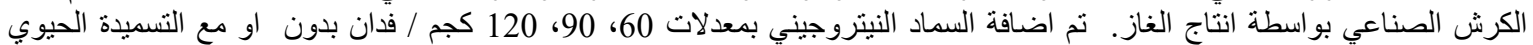

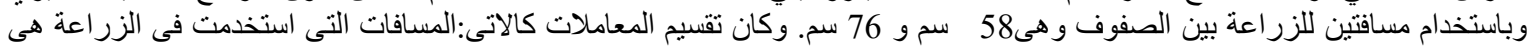

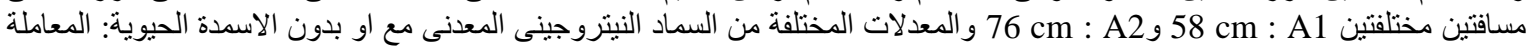

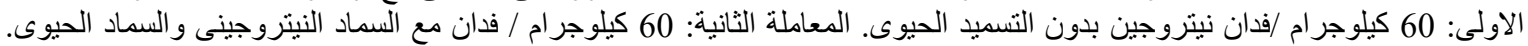

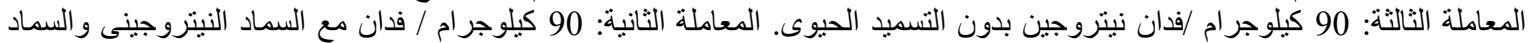

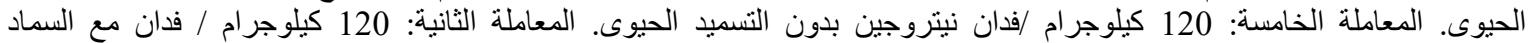

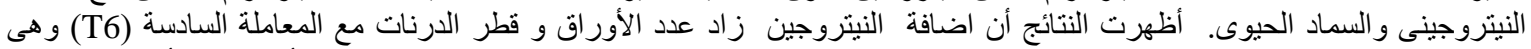

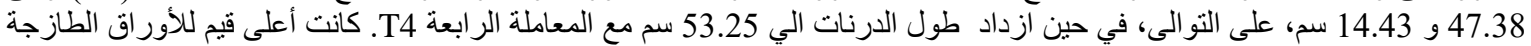

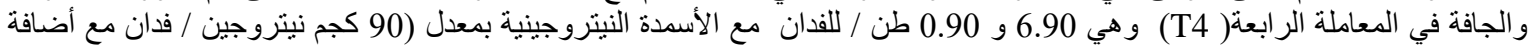

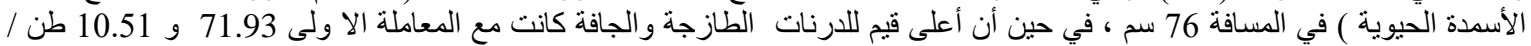

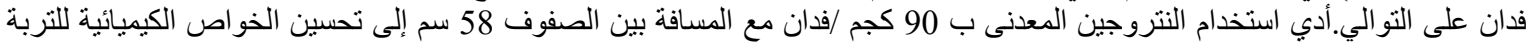
مما صاحبة اعلى انتاج من الدرنات والاوراق /لفدان.
\end{abstract}

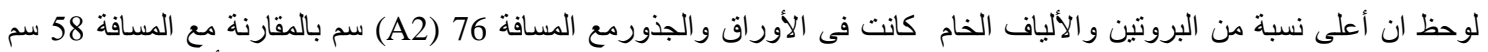

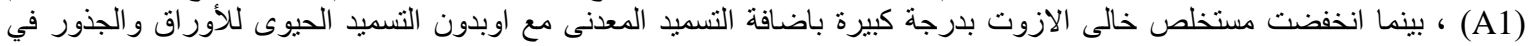

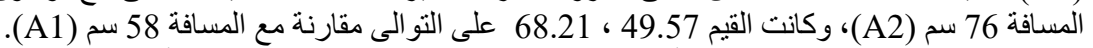

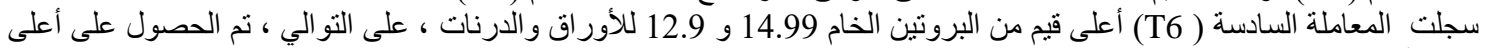

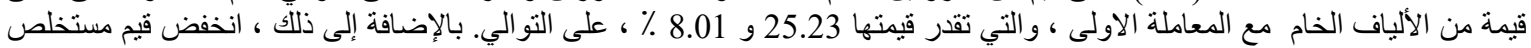

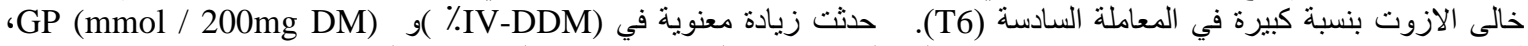

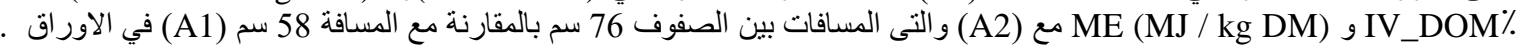

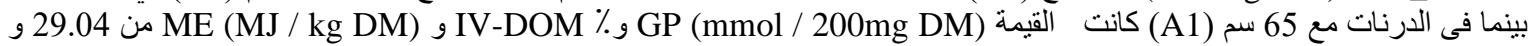

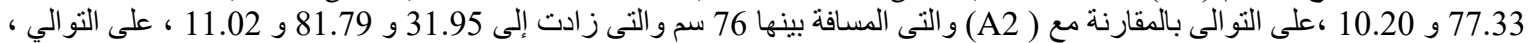

باستثناء 77-DDM \% التى انخفضت من 47.74\% إلى 46.94\%.

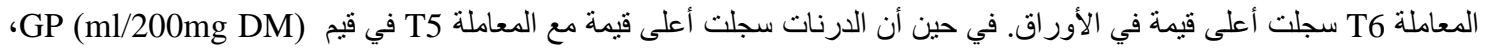

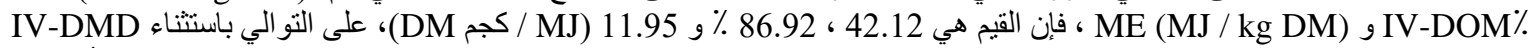

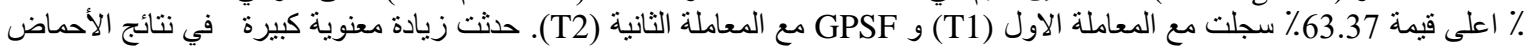

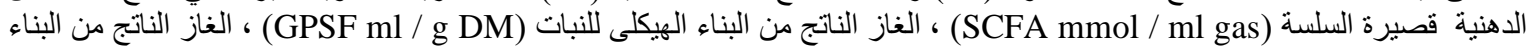

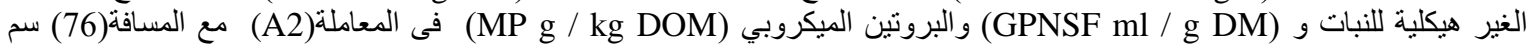

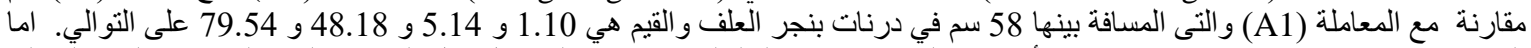

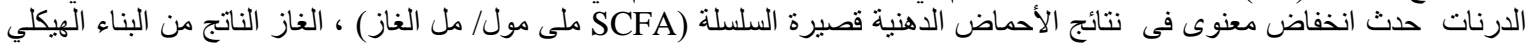

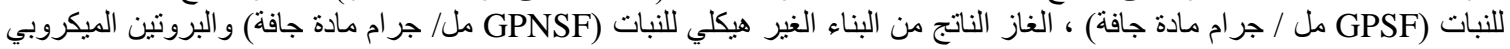

.(MP g / kg DOM)

سجلت T6 (120 كجم / فدان N + سماد حيوي) أعلى قيمة في القيم الهضمية فى الاوراق ـ بينما الدرنات سجلت أعلى قيمة في الغاز

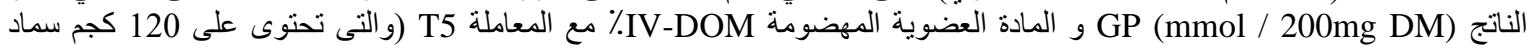

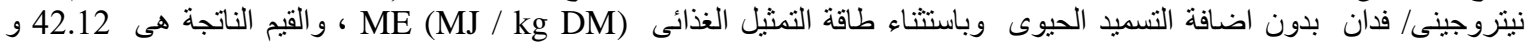

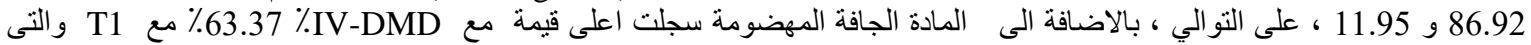

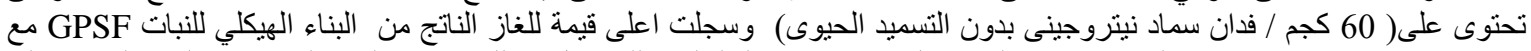
T2 60 T2

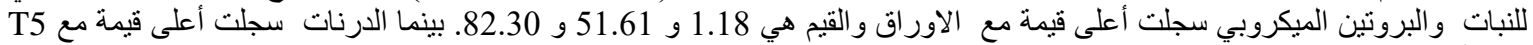

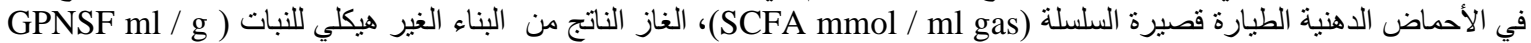

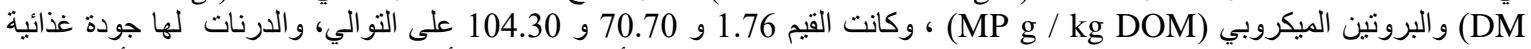

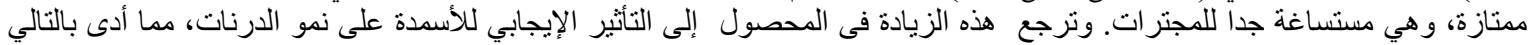

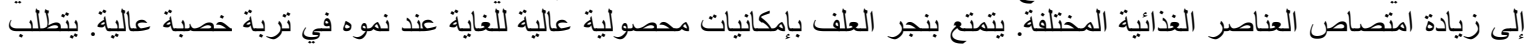
بنجر العلف كميات كبيرة من النيتروجين. 


\section{Ismail and Badr}

اثتت الدراسة ان التسميد النيتروجينى لة ناثير ايجابى على قطر وطول الدرنات وارتبط اعلى نمو مع التسميد النتروجينى 90كوكجم / فدان

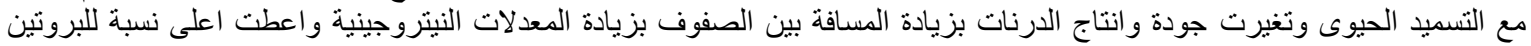

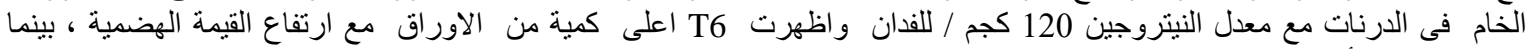

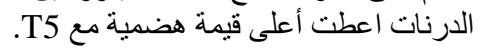

